\title{
A Study on the Factors Influencing Obesity of Korean High School Students - Based on Mental Health Factors -
}

\author{
Hyo-Jeong Kang ${ }^{1)}$, Youngju Jee ${ }^{2)}$ \\ 한국 고등학생의 비만에 영향을 미치는 요인 \\ - 정신건강 요인을 바탕으로 - \\ 강효정1), 지영주2)
}

\begin{abstract}
The purpose of this study was to investigate obesity its mental health factors in korea high school students using data from the 15th 2019 Korea Youth Risk Behavior Web-Based Survey. It is designed to on based mental health factors to provide basic data for managing Obesity. The subjects were 27,073 high school students. The data were analyzed by frequency, t-test, X2-test, and Multiple logistic regression using SPSS/WIN 25.0 program. In addition the factors influencing obesity of Korea high school students were body-shape perception $(\beta=.787, p<.001)$, gender $(\beta=-.285, p<.001)$, grade $(\beta=.053, p<.001)$, Recently fatigue level through sleep for seven days $(\beta=-.016, p<.001)$ significant predictor and accounted for $65.1 \%$ of the variance in Obesity of korea high school students. The factors affecting highly effective intervention techniques need to be applied to the development of programs to prevent obesity of Korea high school students.
\end{abstract}

Keywords: High School Student, Obesity, Body-shape Perception, Gender, Korea Youth Risk Behavior Survey(KYRBS)

$$
\text { 요 약 }
$$

본 연구는 한국 고등학생의 비만에 미치는 영향요인을 정신건강 요인을 바탕으로 파악하기 위하여 시행되었으며, 제15차(2019년) 청소년건강행태조사 통계를 2차 분석한 서술적 조사연구이다. 본 연구

Received(June 4, 2020), Review Result(1st: July 27, 2020, 2nd: September 15, 2020), Accepted(October 28, 2020)

1) (Associate Professor) 47230 Dept. Nursing, Dong-Eui Institude of Sience and Technology of nursing, Busan, Korea

email: kanghj@dit.ac.kr

2) (Assistant Professor, Corresponding Author) 51767 Kyungnam University, College of Nursing, Wol Young Dong, Woryeongbuk 16-gil, Masanhappo-gu, Changwon-si, Gyeongsangnam-do, Korea email: jeeyoungju@kyungnam.ac.kr 
는 한국 고등학교 재학생 27,073명을 대상으로 하였으며, SPSS/WIN 25.0을 이용하여 빈도 분석, t-test, x2-test, 로지스틱 회귀분석으로 통계분석 하였다. 대상자의 비만은 성별, 학년, 성적, 경제 상태, 주관적 체형인지, 최근 7일 동안 잠으로 피로 회복정도, 최근 12 개월 동안 슬픔, 절망감 경험과 유의 미한 상관관계가 있었다. 한국 고등학생의 비만에 영향을 미치는 요인은 주관적 체형인지, 성별, 학년, 최근 7일 동안 잠으로 피로 회복정도 순이었으며 이들 변인들은 대상자의 비만을 총 $65.1 \%$ 설명하는 것으로 나타났다. 본 연구의 결과를 바탕으로 한국 고등학생들의 비만예방과 정신건강을 위한 전략 개발 시 주관적 체형인지, 성별, 학년, 최근 7일 동안 잠으로 피로 회복정도의 고려가 필요할 것으로 사료된다.

핵심어: 고등학생, 비만, 주관적 체형인지, 성별, 청소년건강행태조사

\section{1. 서론}

\section{1 연구의 필요성}

우리나라는 과학기술의 발달과 빠른 경제성장을 이루면서 생활습관뿐 아니라 식생활까지 서구화되 었다. 이에 따라 비만의 발병률이 빠르게 증가하고 있는 실정이다[1]. 2016년 질병관리본부의 국민 건강영양조사에 따르면 만 19세 이상 성인의 비만율은 2001년 32.0\%에서 2016년 35.5\%로, 만 6 18 세의 소아- 청소년 비만율은 2001년 9.1\%에서 2016년 13.3\%로 계속적 증가를 보이고 있다[1]. 특히 소아・청소년 비만율은 2001년 이후 지속적으로 증가하는 추세였고, 이 중 12 18세의 비만율이 더 높은 것으로 보고되었다.

비만인 경우를 성인과 청소년으로 나눴을 때, 세포·생리학적 차이가 있는데, 성인 비만은 지방세 포의 수는 정상으로 유지하되 세포의 크기가 커진다. 그러나 신체가 급성장하는 청소년 비만은 세 포의 수 증가와 호르몬 작용으로 인한 세포의 크기도 커져, 청소년 비만의 $80 \%$ 이상이 성인 비만 으로 이행될 가능성이 높다[2]. 청소년기 비만은 고지혈증, 심혈관 질환, 당뇨병 등 성인병의 발병 률을 증가시키고 신체상의 부정적 영향, 사회적 수치심, 우울, 불안 등의 정신적 문제로 나타나 성 인 비만보다 문제가 심각함을 알 수 있다[3]. 우리나라의 비만 관련 사회·경제적 비용은 2005년 대 비 2013년 2배 이상 증가하였고, 이 중 12 18세 청소년에 대하여 성인까지 비만 상태가 지속되어 비만 관련 질환의 사회·경제적 손실 규모는 약 1 조 3,638 억 원으로 추정되었다[4]. 또한, 식품의약 품안전처에서도 소아 비만의 $40 \%$, 청소년 비만의 $70 \%$ 가 성인 비만으로 이어질 수 있어 소아.청소 년 비만에 관한 사회·경제적 비용 고려를 언급한 바 있다[5]. 따라서 청소년의 비만은 개인의 건강 문제일 뿐 아니라 사회적 문제라 할 수 있겠으며[6], 청소년의 비만예방 및 관리를 위한 노력이 반 드시 필요하다 하겠다.

소아.청소년 비만은 유전적 요인뿐만 아니라 여러 가지 환경적 요인에 영향을 받는다. 맞벌이 부부의 증가는 아이들의 식이 관리를 어렵게 하고 손쉽게 접할 수 있는 패스트푸드 섭취를 증가시 키게 되고 과도한 스마트폰 사용, TV 시청 등으로 인해 활동량은 감소하였다. 소아·청소년에서 비 만 유병률은 연령이 올라갈수록 점점 증가하고 있다[7]. 특히 고등학생들은 질풍노도의 시기여서 정서가 불안정하고 감정의 기복이 심해 주변 환경의 변화에 대해 스트레스를 경험한다[8]. 
한편, 선행연구에서는 소아·청소년의 우울과 스트레스와 같은 정신건강 측면에서 body mass index $(\mathrm{BMI})$ 검사 등 객관적인 체형이나 주관적 체형 인식이 정신건강과 연관이 있다는 결과가 나 타나고 있다[9][10]. 반면, 국내 청소년, 특히 고등학생을 대상으로 한 선행 연구의 수는 미미한 실 정으로 청소년 정신건강 요인 중 우울에만 국한된 경우나[9], 국민건강영양조사를 바탕으로 한 연 구인 것[10] 등을 고려하여 최근의 데이터를 기반으로 다면적 정신건강 요인과 비만과의 관련성을 알아볼 연구가 필요하다고 사료된다. 이를 바탕으로 본 연구에서는 고등학생의 정신건강 요인과 비만과의 관련성을 밝혀냄으로써, 고등학생의 비만예방 및 정신건강을 위한 기초자료로 활용하고 자 한다.

\section{2 연구 목적}

본 연구는 한국 고등학생들의 비만과 각 변수 간의 상관관계를 알아보고, 비만에 영향을 미치는 요인을 규명하여 한국 고등학생들의 비만예방과 정신건강을 위한 전략개발의 기초자료를 제공하고 자 함이다.

\section{2. 연구방법}

\section{1 연구설계}

본 연구는 우리나라 청소년의 정신건강 요인이 비만에 미치는 영향을 파악하기 위하여 제 15 차(2019

년) 청소년건강행태온라인조사 통계를 2차 분석한 서술적 조사연구이다.

\section{2 연구대상 및 방법}

교육부, 보건복지부, 질병관리본부가 우리나라 청소년의 건강행태와 추이를 파악하기 위해 중학교 1 학년 학생부터 고등학교 3학년 학생까지를 대상으로 2019년 제15차 청소년건강행태조사[11]를 온 라인설문으로 시행하였다. 총 800 개 학교의 60,100 명의 대상 중 장기결석, 특수아동, 문장해독장애 학생은 제외한 57,303 명이 참여하여 $95.3 \%$ 의 참여율을 보였다. 본 연구에는 이들 중 고등학교 재학 생 27,073 명을 대상으로 하였다. 본 연구는 질병관리본부에 자료사용을 요청한 뒤 허가를 득하고 획득한 자료를 사용하여 분석하였다.

\section{3 변수선정}

본 연구에서 활용된 도구는 제15차(2019년) 청소년건강행태온라인조사 설문지로 본 연구 목적에 부합하는 일반적 특성, 정신건강 요인 및 비만과 관련된 문항을 연구 변수로 선정하였다. 일반적 
특성을 파악하기 위해서 '성별', ‘학년', ‘성적', ‘경제 상태'를 분석하였다. 성적과 경제 상태는 상, 상중, 중, 중하, 하로 분류된 설문지에 본인 스스로가 인지하는 정도를 체크하도록 하였다. 비만을 정의하기 위한 기준으로 ‘체질량지수'BMI; Body Mass Index)를 활용하였다. 참여자 스스로가 입 력한 체중과 신장의 비로 산출되는 값을 연속변수로 처리하였다[7]. 정신건강 요인으로는 '주관적 건강인지', ‘주관적 체형인지', '평상시 스트레스 인지', ‘최근 7일 동안 잠으로 피로회복 정도', '최 근 12 개월 동안 자살생각', ‘최근 12 개월 동안 자살계획' '최근 12 개월 동안 자살시도 경험'을 분석 하였다. 주관적 건강인지는 매우 건강한 편, 건강한 편, 보통, 건강하지 못한 편과 매우 건강하지 못한 편을, 주관적 체형인지는 매우 마른 편, 약간 마른 편, 보통, 약간 살이 찐 편, 매우 살이 찐 편을, 평상시 스트레스 인지는 대단히 많이 느낌, 많이 느낌, 조금 느낌, 별로 느끼지 않음, 전혀 느끼지 않음으로 분석하였다. 최근 7 일 동안 잠으로 피로회복 정도는 매우 충분하다, 충분하다, 그 저 그렇다, 별로 느끼지 않는다, 전혀 느끼지 않는다로, 최근 12 개월 동안 자살생각, 최근 12 개월 동안 자살계획과 최근 12 개월 동안 자살시도는 경험의 유무로 분석하였다.

\section{4 자료분석 방법}

본 연구에서는 제15차(2019년) 청소년건강행태 온라인조사 통계 자료를 분석하기 위하여 SPSS/ Win 25.0 프로그램을 이용하여 원시자료의 특성을 반영한 복합표본 설계방법으로 분석을 시행하 였다. 복합표본설계 계획 파일은 제15차(2019년) 청소년건강행태 온라인조사에서 제공하는 정보이 며, 계획 변수 계층(Strata), 군집(Cluster), 표본가중값(W)을 지정하고, 추정 방법으로 등확률 비복 원 표본추출 설계, 크기는 모집단 및 유한모집단수정계수(FPC)를 반영하였다. 구체적인 분석방법은 다음과 같다.

1) 일반적 특성(성별, 학년, 성적, 경제 상태)은 빈도와 백분율, 정신건강 요인은 빈도와 백분율, 평균값과 표준편차, 비만에 대해서는 평균값과 표준편차, 최소값과 최대값을 구하였다.

2) 일반적 특성, 정신건강 요인과 비만과의 관련성은 t-test와 교차분석을 하였다.

3) 대상자의 정신건강 요인이 비만에 미치는 영향을 분석하기 위해 로지스틱 회귀분석을 하였 다. 선행된 교차분석에서 유의한 차이가 있었던 변수(유의확률 $\mathrm{p}<.05)$ 를 통제변수로 하였고, 각 요 인에 대한 교차비와 $95 \%$ 신뢰구간을 산출하였다.

\section{3. 연구결과}

\section{1 대상자의 일반적 특성}

본 연구대상자의 일반적 특성 중 성별은 남성 $51.7 \%$, 여성 $48.3 \%$ )이었고 학년은 1학년이 $33.3 \%, 2$ 학년이 $32.4 \%$, 3학년이 $34.3 \%$ 이었다. 성적은 상 $9.8 \%$, 상중 $22.6 \%$, 중 $31.8 \%$, 중하 $24.6 \%$, 하 $11.2 \%$ 이었다. 경제 상태는 상 $8.3 \%$, 상중 $25.9 \%$, 중 $50.3 \%$, 중하 $12.8 \%$, 하 $2.8 \%$ 이었다. $\mathrm{BMI}$ 의 평균과 
표준편차는 $22.04 \pm 3.55$ 였고 최소값 11.75 , 최대값 35.21 이었다[Table 1].

[표 1] 일반적 특성

[Table 1] General Characteristics

$(\mathrm{N}=27073)$

\begin{tabular}{|c|c|c|c|c|}
\hline Variables & Categories & $\mathrm{n}(\%)$ & Mean \pm SD & Min-Max \\
\hline \multirow{2}{*}{ 성별 } & 남자 & $14,008(51.7)$ & & \\
\hline & 여자 & $13,065(48.3)$ & & \\
\hline \multirow{3}{*}{ 학년 } & 고1 & $9,022(33.3)$ & & \\
\hline & 고2 & $8,774(32.4)$ & & \\
\hline & 고3 & $9,277(34.3)$ & & \\
\hline \multirow{5}{*}{ 성적 } & 상(1) & $2,666(9.8)$ & \multirow{5}{*}{$3.05 \pm 1.148$} & \\
\hline & 중상(2) & $6,123(22.6)$ & & \\
\hline & 중(3) & $8,610(31.8)$ & & \\
\hline & 중하(4) & $6,654(24.6)$ & & \\
\hline & 하(5) & $3,020(11.2)$ & & \\
\hline \multirow{5}{*}{ 경제 상태 } & 상(1) & $2,239(8.2)$ & \multirow{5}{*}{$2.76 \pm 0.879$} & \\
\hline & 중상(2) & $7,005(25.9)$ & & \\
\hline & 중(3) & $13,609(50.3)$ & & \\
\hline & 중하(4) & $3,460(12.8)$ & & \\
\hline & 하(5) & $760(2.8)$ & & \\
\hline BMI & & & $22.04 \pm 3.55$ & $11.75-35.21$ \\
\hline
\end{tabular}

\section{2 대상자의 정신건강 요인의 정도}

대상자의 주관적 건강인지 정도는 매우 건강한 편 $24.6 \%$, 건강한 편 $42.7 \%$, 보통 $23.8 \%$, 건강하지 못한 편 $8.6 \%$, 매우 건강하지 못한 편 $0.7 \%$ 이었으며, 주관적 체형인지 정도는 매우 마른 편 $4.3 \%$, 약간 마른 편 $20.2 \%$, 보통 $35.8 \%$, 약간 살이 찐 편 $33.7 \%$, 매우 살이 찐 편 $6.0 \%$ 이었다. 평상시 스 트레스 인지 정도는 대단히 많이 느낌 $13.0 \%$, 많이 느낌 $29.4 \%$, 별로 느끼지 않음 $13.3 \%$, 별로 느 끼지 않음 $13.3 \%$, 전혀 느끼지 않음 $3.2 \%$ 이었고 최근 7 일 동안 잠으로 피로회복 정도는 매우 충분 하다 $4.3 \%$, 충분하다 $11.4 \%$, 그저 그렇다 $30.7 \%$, 별로 느끼지 않는다 $30.2 \%$, 전혀 느끼지 않는다 $21.5 \%$ 이었다. 최근 12 개월 동안 슬픔, 절망감을 $29.3 \%$, 자살생각은 $11.8 \%$, 자살계획은 $3.1 \%$, 자살시 도는 $2.1 \%$ 가 경험하였다고 나타났다[Table 2].

[표 2] 정신건강 요인

[Table 2] Mental Health Characteristics

$(\mathrm{N}=27073)$

\begin{tabular}{|c|c|c|c|}
\hline Variables & Categories & $\mathrm{n}(\%)$ & Mean $\pm \mathrm{SD}$ \\
\hline \multirow{4}{*}{ 주관적 건강인지 } & 매우 건강한 편(1) & $6,656(24.6)$ & \multirow{3}{*}{$2.18 \pm 0.92$} \\
\cline { 2 - 3 } & 건강한 편(2) & $11,467(42.4)$ & \\
\cline { 2 - 3 } & 보통(3) & $6,452(23.8)$ & \\
\cline { 2 - 3 } & 건강하지 못한 편(4) & $2,321(8.6)$ & \\
\cline { 2 - 3 } & 매우 건강하지 못한 편(5) & $177(0.6)$ & \\
\hline
\end{tabular}


A Study on the Factors Influencing Obesity of Korean High School Students - Based on Mental Health factors -

\begin{tabular}{|c|c|c|c|}
\hline \multirow{5}{*}{ 주관적 체형인지 } & 매우 마른 편(1) & $1,175(4.3)$ & \multirow{5}{*}{$3.17 \pm 0.96$} \\
\hline & 약간 마른 편(2) & $5,468(20.2)$ & \\
\hline & 보통(3) & $9,681(35.8)$ & \\
\hline & 약간 살이 찐 편(4) & $9,116(33.7)$ & \\
\hline & 매우 살이 찐 편(5) & $1,633(6.0)$ & \\
\hline \multirow{5}{*}{ 평상시 스트레스 인지 } & 대단히 많이 느낌(1) & $3,529(13.0)$ & \multirow{5}{*}{$2.64 \pm 0.97$} \\
\hline & 많이 느낌(2) & $7,970(29.4)$ & \\
\hline & 조금 느낌(3) & $11,105(41.0)$ & \\
\hline & 별로 느끼지 않음(4) & $3,602(13.3)$ & \\
\hline & 전혀 느끼지 않음(5) & $867(3.3)$ & \\
\hline \multirow{5}{*}{ 최근 7일 동안 잠으로 피로 회복정도 } & 매우 충분하다(1) & $1,165(4.3)$ & \multirow{5}{*}{$3.55 \pm 1.08$} \\
\hline & 충분하다(2) & $3,075(11.4)$ & \\
\hline & 그저 그렇다(3) & $8,305(30.7)$ & \\
\hline & 별로 느끼지 않는다(4) & $8,715(32.2)$ & \\
\hline & 전혀 느끼지 않는다(5) & $5,813(21.4)$ & \\
\hline \multirow{2}{*}{ 최근 12개월 동안 슬픔, 절망감 경험 } & 없다(1) & $19,146(70.7)$ & \\
\hline & 있다(2) & $7,927(29.3)$ & \\
\hline \multirow{2}{*}{ 최근 12 개월 동안 자살생각 } & 없다(1) & $23,866(88.2)$ & \\
\hline & 있다(2) & $3,187(11.8)$ & \\
\hline \multirow{2}{*}{ 최근 12개월 동안 자살계획 } & 없다(1) & $26,232(96.9)$ & \\
\hline & 있다(2) & $841(3.1)$ & \\
\hline \multirow{2}{*}{ 최근 12 개월 동안 자살시도 } & 없다(1) & $26,514(97.9)$ & \\
\hline & 있다(2) & $559(2.1)$ & \\
\hline
\end{tabular}

\section{3 변인과 비만과의 상관성}

대상자의 비만은 성별 $(\mathrm{r}=-.205, \mathrm{p}<.001)$, 학년 $(\mathrm{r}=.079, \mathrm{p}<.001)$, 성적 $(\mathrm{r}=.024, \mathrm{p}<.001)$, 경제 상태 $(\mathrm{r}=.025, \mathrm{p}<.001)$, 주관적 체형인지 $(\mathrm{r}=.752, \mathrm{p}<.001)$, 최근 7일 동안 잠으로 피로 회복정도 $(\mathrm{r}=-.042$, $\mathrm{p}<.001)$, 최근 12 개월 동안 슬픔, 절망감 경험 $(\mathrm{r}=-.019, \mathrm{p}=.001)$ 과 유의미한 상관관계가 있었다.

[표 3] 변인과 비만과의 상관성

[Table 3] Correlation between Variables and Obesity

$(\mathrm{N}=27073)$

\begin{tabular}{|c|c|c|c|c|c|c|c|c|c|c|c|c|c|}
\hline & (1) & (2) & (3) & (4) & (5) & (6) & (7) & (8) & (9) & (10) & (11) & (12) & (13) \\
\hline & \multicolumn{13}{|c|}{$\mathrm{r}(\mathrm{p})$} \\
\hline (1) & 1 & & & & & & & & & & & & \\
\hline (2) & $\begin{array}{c}-.205 \\
(<.001)\end{array}$ & 1 & & & & & & & & & & & \\
\hline (3) & $\begin{array}{c}.079 \\
(<.001)\end{array}$ & -0.009 & 1 & & & & & & & & & & \\
\hline (4) & $\begin{array}{c}.042 \\
(<.001)\end{array}$ & .657 & $\begin{array}{l}-.015 \\
0.014\end{array}$ & 1 & & & & & & & & & \\
\hline (5) & $\begin{array}{c}.025 \\
(<.001)\end{array}$ & $\begin{array}{c}.041 \\
(<.001)\end{array}$ & $\begin{array}{c}0.048 \\
(<.001)\end{array}$ & $\begin{array}{c}0.257 \\
(<.001)\end{array}$ & 1 & & & & & & & & \\
\hline (6) & $\begin{array}{c}.005 \\
0.408\end{array}$ & $\begin{array}{c}.212 \\
(<.001)\end{array}$ & $\begin{array}{c}.047 \\
(<.001)\end{array}$ & $\begin{array}{c}.078 \\
(<.001)\end{array}$ & $\begin{array}{l}.151 \\
(<.001)\end{array}$ & 1 & & & & & & & \\
\hline (7) & .752 & .125 & .032 & .061 & .048 & .072 & 1 & & & & & & \\
\hline
\end{tabular}




\begin{tabular}{|c|c|c|c|c|c|c|c|c|c|c|c|c|c|}
\hline & $(<.001)$ & $(<.001)$ & $(<.001)$ & (<.001) & $(<.001)$ & (<.001) & & & & & & & \\
\hline (8) & $\begin{array}{c}0.008 \\
(0.186) \\
\end{array}$ & $\begin{array}{c}-.205 \\
(<.001) \\
\end{array}$ & $\begin{array}{c}-.024 \\
(<.001) \\
\end{array}$ & $\begin{array}{c}-.046 \\
(<.001) \\
\end{array}$ & $\begin{array}{c}-.090 \\
(<.001) \\
\end{array}$ & $\begin{array}{c}-.330 \\
(<.001) \\
\end{array}$ & $\begin{array}{c}-.068 \\
(<.001) \\
\end{array}$ & 1 & & & & & \\
\hline (9) & $\begin{array}{c}-.042 \\
(<.001) \\
\end{array}$ & $\begin{array}{c}.164 \\
(<.001) \\
\end{array}$ & $\begin{array}{l}.012 \\
0.049 \\
\end{array}$ & \begin{tabular}{|l|l|}
-.008 \\
0.181 \\
\end{tabular} & $\begin{array}{c}.060 \\
(<.001) \\
\end{array}$ & $\begin{array}{c}.214 \\
(<.001) \\
\end{array}$ & $\begin{array}{c}.029 \\
(<.001) \\
\end{array}$ & $\begin{array}{c}-.332 \\
(<.001) \\
\end{array}$ & 1 & & & & \\
\hline (10) & $\begin{array}{c}.019 \\
(0.001) \\
\end{array}$ & $\begin{array}{c}.125 \\
(<.001) \\
\end{array}$ & $\begin{array}{c}.027 \\
(<.001) \\
\end{array}$ & $\begin{array}{c}.064 \\
(<.001) \\
\end{array}$ & $\begin{array}{c}.054 \\
(<.001) \\
\end{array}$ & $\begin{array}{c}.195 \\
(<.001) \\
\end{array}$ & $\begin{array}{c}.030 \\
(<.001) \\
\end{array}$ & $\begin{array}{c}-373 \\
(<.001) \\
\end{array}$ & $\begin{array}{c}.174 \\
(<.001) \\
\end{array}$ & 1 & & & \\
\hline (11) & $\begin{array}{c}.010 \\
(.114) \\
\end{array}$ & $\begin{array}{c}0.095 \\
(<.001) \\
\end{array}$ & $\begin{array}{r}-.006 \\
0.302 \\
\end{array}$ & $\begin{array}{c}.049 \\
(<.001) \\
\end{array}$ & $\begin{array}{c}.066 \\
(<.001) \\
\end{array}$ & $\begin{array}{c}.201 \\
(<.001) \\
\end{array}$ & $\begin{array}{c}.036 \\
(<.001) \\
\end{array}$ & $\begin{array}{c}-.294 \\
(<.001) \\
\end{array}$ & $\begin{array}{c}.134 \\
(<.001) \\
\end{array}$ & $\begin{array}{c}362 \\
(<.001) \\
\end{array}$ & 1 & & \\
\hline (12) & $\begin{array}{l}-.003 \\
(.568) \\
\end{array}$ & $\begin{array}{c}.040 \\
(<.001) \\
\end{array}$ & $\begin{array}{r}-.016 \\
0.007 \\
\end{array}$ & $\begin{array}{c}.024 \\
(<.001) \\
\end{array}$ & $\begin{array}{c}.043 \\
(<.001) \\
\end{array}$ & $\begin{array}{c}.108 \\
(<.001) \\
\end{array}$ & $\begin{array}{r}.003 \\
0.579 \\
\end{array}$ & $\begin{array}{c}-.149 \\
(<.001) \\
\end{array}$ & $\begin{array}{c}.057 \\
(<.001) \\
\end{array}$ & $\begin{array}{c}.187 \\
(<.001) \\
\end{array}$ & $\begin{array}{c}.431 \\
(<.001) \\
\end{array}$ & 1 & \\
\hline (13) & $\begin{array}{c}.007 \\
(0.240) \\
\end{array}$ & $\begin{array}{c}.050 \\
(<.001)\end{array}$ & $\begin{array}{l}-.017 \\
0.006 \\
\end{array}$ & $\begin{array}{c}.042 \\
(<.001) \\
\end{array}$ & $\begin{array}{c}.048 \\
(<.001) \\
\end{array}$ & $\begin{array}{c}.089 \\
(<.001)\end{array}$ & $\begin{array}{c}.015 \\
0.017\end{array}$ & $\begin{array}{c}-.137 \\
(<.001)\end{array}$ & $\begin{array}{c}.050 \\
(<.001) \\
\end{array}$ & $\begin{array}{c}.171 \\
(<.001) \\
\end{array}$ & $\begin{array}{c}.361 \\
(<.001) \\
\end{array}$ & $\begin{array}{c}.480 \\
(<.001) \\
\end{array}$ & 1 \\
\hline
\end{tabular}

Note; (1);BMI, (2);성별, (3);학년, (4);성적, (5);경제 상태, (6);주관적 건강인지, (7);주관적 체형인지, (8);평상시 스트레스 인지, (9);최근 7일 동안 잠으로 피로 회복정도, (10);최근 12개월 동안 슬픔, 절망감 경험, (11);최근 12 개월 동안 자살생각, (12);최근 12 개월 동안 자살계획, (13);최근 12 개월 동안 자살시도

\section{4 대상자의 비만에 미치는 영향}

한국 고등학생의 비만에 영향을 미치는 일반적 특성과 정신건강 요인을 규명하기 위해 로지스틱 회귀분석을 하였고 결과는 [Table 4]와 같다. 비만에 통계적으로 유의한 차이를 보였던 성별, 학년, 성적, 경제 상태, 주관적 체형인지, 최근 7 일 동안 잠으로 피로 회복정도, 최근 12 개월 동안 슬픔, 절망감 경험을 종속변수로 하여 로지스틱 회귀분석을 하였다. 한국 고등학생의 비만에 대한 회귀 모형은 유의하였으며(F=7217.644, $\mathrm{p}<.001)$, 다중공선성을 분석한 결과 공차한계(tolerance)는 0.1이상 이었고 분산팽창인자(Variance Inflation Factor, VIF)는 1.000 1.081으로 기준치인 10을 넘지 않아 다중공선성의 문제가 없었다. 또한 잔차의 독립성 검증을 위해 Durbin-Watson값을 구한 결과 1.186 으로 2에 가깝고 자기상관(auto-correlation)이 없는 것으로 확인되었다. 대상자의 비만에 가장 큰 영향을 미친 요인은 주관적 체형인지 $(\beta=.787, p<.001)$ 이었고, 다음으로 성별 $(\beta=-.285, p<.001)$, 학 년 $(\beta=.053, \mathrm{p}<.001)$, 최근 7일 동안 잠으로 피로 회복정도 $(\beta=-.016, \mathrm{p}<.001)$ 순으로 나타났으며 이 변 인들은 한국 고등학생의 비만을 총 $65.1 \%$ 설명하는 것으로 나타났다[Table 4].

[표 4] 비만에 영향을 미치는 정신건강 요인

[Table 4] Influencing Factors on BMI

$(\mathrm{N}=27073)$

\begin{tabular}{|c|c|c|c|c|c|c|c|}
\hline & \multirow{2}{*}{ B } & \multirow{2}{*}{ SE } & \multirow{2}{*}{$\beta$} & \multirow{2}{*}{$\mathrm{t}$} & \multirow{2}{*}{$\mathrm{p}$} & \multicolumn{2}{|c|}{ 공선성 } \\
\hline & & & & & & 공차 & VIF \\
\hline (Constant) & 14.973 & 0.111 & & 134.951 & $<.001$ & & \\
\hline 성별 & -2.027 & 0.026 & -.285 & -77.430 & $\langle .001$ & .979 & 1.022 \\
\hline 학년 & 0.229 & 0.016 & .053 & 14.703 & $\langle .001$ & .946 & 1.058 \\
\hline 성적 & -0.002 & 0.012 & -.001 & -0.181 & .857 & .954 & 1.048 \\
\hline 경제 상태 & -0.008 & 0.015 & -.002 & -0.505 & .613 & .949 & 1.054 \\
\hline 주관적 체형인지 & 2.905 & 0.013 & .787 & 216.893 & $\langle .001$ & .927 & 1.079 \\
\hline 최근 7일 동안 잠으로 피로회복정도 & -0.052 & 0.012 & -.016 & -4.314 & $\langle .001$ & .925 & 1.081 \\
\hline 최근 12 개월 동안 슬픔절망감경험 & -0.046 & 0.029 & -.006 & -1.600 & .110 & .995 & 1.005 \\
\hline
\end{tabular}




\section{4. 논의}

본 연구는 한국 고등학생들의 비만과 각 변수 간의 상관관계를 알아보고, 비만에 영향을 미치는 요인을 규명하여 한국 고등학생들의 비만예방과 정신건강을 위한 전략개발의 기초자료를 제공하고 자 진행되었다.

한국 고등학생의 비만은 성별, 학년, 성적, 경제 상태, 주관적 체형인지, 최근 7일 동안 잠으로 피로 회복정도 및 최근 12 개월 동안 슬픔, 절망감 경험과 유의미한 상관관계가 있었다. 또한 한국 고등학생의 비만에 영향을 미치는 요인을 알기 위한 회귀분석의 결과, 대상자의 비만에 가장 큰 영향을 미친 요인은 주관적 체형인지이었고, 다음으로 성별, 학년, 최근 7일 동안 잠으로 피로 회 복정도 순으로 나타났으며 이들 변인들은 대상자의 비만을 총 $65.1 \%$ 설명하는 것으로 나타났다.

한국 고등학생의 비만에 가장 큰 영향을 미치는 요인은 주관적 체형인지로 나타났다. 이는 대상 은 다르지만 현역병을 대상으로 한 Lee[12]의 연구에서 주관적 체형인식이 BMI에 영향을 미치는 요인으로 나타난 연구결과와 유사하나, 주관적 체형인지 정도가 높을수록 $\mathrm{BMI}$ 가 낮아진 결과는 본 연구와 상반된 결과이다. 이는 본 연구의 대상자는 사춘기인 고등학생인 점, 여학생이 과반수 비중인 것에서 기인한 것으로 사료된다. 따라서 고등학교에서는 아동에서 성인으로의 과도기인 고 등학생들의 체형인식에 대한 차이를 알고 올바른 체형인식에 대한 맞춤형 교육이 필요할 것으로 사료된다.

대상자의 비만에 주관적 체형인지 다음으로 영향을 미친 요인은 성별이었다. 이는 Chun 과 Hwang[3]의 연구결과를 지지한다. 만 11-18세의 청소년을 대상으로 연구한 선행연구[3]에서는 실 제 비만도가 과체중 이상인 여학생 군에서는 정상이하군과 비교하여 스트레스 경험률에서 통계적 으로 유의하게 높은 결과를 보였다. 또한 Nam과 Park[13]의 연구에서는 남학생은 자신을 저체중 으로 인식할 경우 신체 만족도 및 자아존중감이 낮고, 여학생은 자신을 저체중으로 인식하는 경우 자아존중감이 높음을 보여 준 연구가 있다. 따라서 남학생과 여학생의 비만스트레스 고위험군이 비만스트레스를 풀 수 있고 관리할 수 있는 방안 마련이 필요할 것으로 사료된다.

한국 고등학생들의 학년은 비만에 영향을 미친 세 번째 요인으로 학년이 올라갈수록 비만도가 높아진다[7]. Chun과 Hwang[3]의 연구에서는 학년이 비만에 영향을 미치는 요인은 아니었으나 3 학년이 저학년보다 과체중군과 비만군의 비율이 높게 보였으며, 고등학교 3학년 학생은 입시 및 학업으로 신체적 활동이 감소하고 올바르지 못한 식습관이 나타낸 결과로 사료된다. 따라서 고등 학교 3학년 학생을 대상으로 신체활동을 증가시키고 올바른 식습관을 형성할 수 있는 건강교육프 로그램이 교육과정에 편성될 수 있는 환경적 여건 마련이 시급할 것으로 생각된다. 또한 고교유형 별로 졸업 후 목표에 따라 처한 상황에 따른 비만 스트레스도 다를 것이므로 추후 고교유형별로 확대하여 반복연구가 필요하리라 생각된다.

한국 고등학생의 비만에 영향을 미치는 네 번째 요인은 최근 7일 동안 잠으로 피로 회복정도이 
었다. Lee[14]의 연구에서 청소년을 대상으로 수면시간과 체질량지수의 관계를 알아보았는데, 수면 시간이 짧은 군일수록 비만율의 증가가 나타났다. 반면 $\mathrm{Jo}[15]$ 의 연구에서는 중·고등학생 모두 수 면시간과 수면 충족도는 비만과 유의미한 상관관계를 보였으나 수면시간이 증가할수록 비만율이 증가함이 나타났다. 이러한 결과는 수면과 비만이 아닌 다른 변수의 교란으로 발생 가능한 것으로 사료되며 이러한 변인들을 고려한 비만과 수면의 인과관계에 대한 후속 연구가 필요하다고 사료된 다.

본 연구의 결과를 바탕으로 고등학생들의 비만예방과 정신건강을 위한 전략개발 시 주관적 체 형인지, 성별, 학년, 최근 7일 동안 잠으로 피로 회복정도의 고려가 필요할 것이다. 또한 고등학생 의 정신건강요인을 중심으로 $\mathrm{BMI}$ 에 미치는 영향요인을 분석 연구의 필요성을 제기한 바에 의의가 있다 사료된다.

\section{5. 결론 및 제언}

본 연구는 한국 고등학생의 정신건강 요인을 바탕으로 비만에 미치는 영향을 규명하여, 비만예방 과 정신건강을 위한 기초자료를 제공하고자 진행되었다. 대상자의 비만은 성별, 학년, 성적, 경제 상태, 주관적 체형인지, 최근 7 일 동안 잠으로 피로 회복정도, 최근 12 개월 동안 슬픔, 절망감 경험 과 유의미한 상관관계가 있었다. 대상자의 비만에 가장 큰 영향을 미친 요인은 주관적 체형인지이 었고, 다음으로 성별, 학년, 최근 7일 동안 잠으로 피로 회복정도 순으로 나타났으며 이 변인들은 한국 고등학생의 비만을 총 $65.1 \%$ 설명하는 것으로 나타났다. 이에 고등학생의 비만예방 및 관리 를 위해 이들을 고려한 전략을 세워야 할 것이다.

\section{References}

[1] Korea Centers for Disease Control Prevention, 2016 National Health Statistics Analysis Results, Health and Walfare Department Health Policy Division, (2017), https://www.cdc.go.kr/CDC/contents/ CdfKrContentView.jsp?cid=60949\&menuIds=HOME001-MNU1130-MNU1639-MNU1749-MNU1761

[2] R. F. Guo, P. A. Ward, Mediators and regulation of neutrophil accumulation in inflammatory responses in lung: insights from the IgG immune complex model, Free Radical Biology Medicine, (2002), Vol.33, No.3, pp.303-310.

[3] Y. E. Chun, H. Y. Hwang, Study of relationship among Obesity level, eating habit, Nutrition knowledge and Dietary attitude in High school students, Asia-pacific Journal of Multimedia Services Convergent with Art, Humanities, and Sociology, (2019), Vol.9, No.9, pp.533-546, DOI:10.35873/ajmahs.2019.9.9.046

[4] Y. H. Jung, S. J. Ko, H. J. Lim, The Socioeconomic Cost of Adolescent Obesity, Health and Social Welfare Review, (2010), Vol.30, No.1, pp.195-219, DOI: 10.15709/hswr.2010.30.1.195 
[5] S. H. Kim, S. K. Jin, A Panel Study on the Effect of Obesity and the Chronic Diseases on the Health Care Expenditures, Health Policy and Management, (2015), Vol.25, No.3, pp.152-161, UCI: G704-000400.2015.25.3.005

[6] J. H. Kim, I. K. Jung, Relationships among physical education class, physical activity, and health-related factor in male adolescents, The Journal of Learner-Centered Curriculum and Instruction, (2018), Vol.18, No.9, pp.757-779, DOI:10.22251/jlcci.2018.18.9.757

[7] S. K. Lee, Longitudinal Trajectory Types and Influencing Factors of Child Body Mass Index, Journal of Institute for Social Sciences, (2017), Vol.28, No.4, pp.19-42, DOI: http;//dx.doi.org/10.1881/jlss.2017.10.28.4.19

[8] J. W. Song, H. I. Jo, The Influence of Daily Stress on Psychological Well-Being of Adolescents: Mediating Effects of Cognitive Emotion Regulation Strategies, Korean Journal of Youth Studies, (2018), Vol.25, No.8, pp.103-129, DOI: $10.21509 /$ KJYS.2018.08.25.8.103

[9] H. W. Byeon, The relationship between BMI, weight perception and depression-like symptoms in Korean middle school students, Journal of Korea Academea-Industrial cooperation Society, (2013), Vol.14, No.12, pp.6317-6323, DOI: 10.5762/KAIS.2013.14.12.6317

[10] I. C. Hwang, K. S. Lee, D. K. Park, E. Y. Jung, C. H. Choi, S. J. Cho, S. M. Bae, Association with Self-Perception for Obesity and Mental Health among Korean Adolescent, Korean Journal of Child \& Adolescent Psychiatry, (2011), Vol.22, No.2, pp.112-119, UCI: G704-001951.2011.22.2.009

[11] The 15th Korea Youth Risk Behavior Survey, Ministry of Education, Ministry of Health and Welfare, Disease Control and Prevention, (2019)

[12] H. J. Lee, Influence on Enlisted Soldiers' Health behavior, Body-shape perception, and Weight control toward the BMI change, Journal of Korea Academia-Industrial cooperation Society, (2015), Vol.16, No.5, pp.3353-3360, DOI: 10.5762/KAIS.2015.16.5.3353

[13] S. J. Nam, J. H. Park, Adolescents' Satisfaction of Body and Self-Esteem According to Obesity and Subjective Perception of Body: Verification of Moderating Effect of Sex, The Korean Journal Obesity, (2013), Vol.22, No.4, pp.251-253, UCI: G704-001955.2013.22.4.010

[14] B. I. Lee, Association between Sleep Duration and Body Mass Index among South Korean Adolescents, Korean Journal of Health Promotion, (2015), Vol.15, No.1, pp.16-23, DOI: 10.15384/kjhp.2015.15.1.16

[15] D. H. Jo, The Influence of Sleep Behavior on Obesity in Adolescents, Department of Public Health Graduate School of Public Health and Welfare, Dankook University, Master's thesis, (2019) 